\title{
In vitro studies on anti asthmatic, analgesic and anti convulsant activities of the medicinal plant Bryonia laciniosa.Linn
}

\author{
Jayarama Reddy ${ }^{1}$, Gnanasekaran D. ${ }^{2}$, Vijay D. ${ }^{{ }^{3}}$ and Ranganathan T.V. ${ }^{1}$ \\ ${ }^{1}$ St. Joseph's Post graduate and Research Centre, 36, Langford Road, Bangalore-560027. \\ ${ }^{2}$ Bharati College of Pharmacy, Bharati Nagara, Mandya, Karnataka. \\ ${ }^{3}$ Research Department of Plant Biology and Biotechnology, Arignar Anna Government Arts College, \\ Viluppuram, Tamil Nadu.
}

\begin{abstract}
The study was carried out to ascertain anti asthmatic, analgesic and anti convulsant activities of the medicinal plant Bryonia Laciniosa. The anti asthmatic activity was estimated by mesenteric mast cell count by Atopic allergy method. Eddy's hot plate and Analgesiometer tests were used to assess the analgesic activity of Bryonia Laciniosa. Anticonvulsant activity was evaluated by Maximum electroshockinduced seizure test. The results indicated that $70 \%$ alcoholic extract of Bryonia laciniosa increased the antiasmatic activity, analgestic activity and also anticonvulsant activity.
\end{abstract}

Keywords: Bryonia Laciniosa, Atopic allergy method, Eddy's hot plate analgesio meter, Electric shock method.

\section{Introduction}

Man's acquaintance with the medicinal properties of plants is of great antiquity. Even the higher mammals are said to be aware of the curative aspects of the plant kingdom. Atharva veda suggests that man learnt the therapeutic value of plants by observing the behavior of wild animals and birds in disease. Charaka Samhita concedes the knowledge of pharmacognosy on the part of primitive hunters, shepherds, cowherds and forest tribes. But a systematic and rational knowledge of medicinal plants is an achievement of Ayurveda, which has its roots even in the early hymns of Rigveda, the vedic index, which lists as many as two hundred and sixty medicinal herbs referred to in vedic corpus. Arthshastra provides a list of three hundred and eighty five and charaka's list includes five hundred medicinal plants. They are all named, described, classified and their specific therapeutic action is indicated. Medicinal plants are commonly available in abundance, especially in the tropics. Medicinal plants offer the local population and others immediate access 15 such plants and effective products for use in the treatment of illness through self medication. Furthermore, plants are valuable for modern medicine in four basic ways.

- They are used as sources of direct therapeutic agents.

- They serve as raw materials base for elaboration of more complex semi synthetic chemical compounds

- The chemical structures derived from plant sources can be used as models for new synthetic compounds

- Finally plants can be used as taxonomic markers for the discovery of new compounds.

Plant derived medicines are used in self medication in all cultures. However only a fraction of the world's available plants have been studied. Since the discovery and use of sulpha drugs, antibiotics such as penicillin's and synthetic drugs, there has been a dramatic decline in the popularity of medicinal plants in therapy. In a number of cases, these synthetic drugs have caused side effects or adverse reactions that were not for seen in preclinical and clinical examinations. As a result, a resurgence of interest in the study and use of medicinal plants has been taken place during the last two decades. As a result of modern isolation techniques and pharmacological testing procedures, new plant drugs found their way into modern medicine as purified substances rather than in the form of galenical preparations. Such use of single pure compounds, including synthetic drugs, is not without its limitations and in recent years there has been an immense revival in the interest of herbal and homeopathic system, both of which rely heavily on plant sourced [1].

"Health for all by the year 2000" is both a goal and a process which engages each nation of the world to improve the health of its people. This concept calls for a level of health that will permit all people to lead a socially and economically productive life. The success of any health system depends on the ready availability and use of suitable drugs on a sustainable basis. Medicinal plants have always played a key role in world of health. WHO has also done its share to further awareness of the importance of traditional medicines to the majority of world's population, and to promote increased rational exploitation for all present and future peoples of the world of safe and effective practices, including the use of medicinal plants .One of the major problems encountered with the use of natural products, including herbs, is maintaining product uniformity. Doubts have been raised for the use of herbal drugs on the on the reason that:

- Herbs of different origin are often known by the same popular name

- Plants growing in different climatic soil and seasonal conditions do not have identical chemical constituents or therapeutic effect 
- Process of collection (fresh, shade and sun dried), extraction processing and storage of herbal medicines cause variation in potency and safety

- No specific standards for herbal medicines have been prescribed and

- Non availability of these herbal medicines in suitable dosage forms create difficulty in administration

These short comings have delayed the integration of some of the well recognized Ayurvedic or Unani recipies in the modern system of medicine. Safety should be the overriding criterion in the selection of herbal medicines for use in health service system. Procedures for screening, chemical analysis, clinical trials and regulatory measures should be applied to the various groups of product namely

- Whole, or parts of plants

- Crude extracts or

- Pure phytochemicals

Where as a less stringent selection procedur could be applied to the first two groups, the procedure applied to the last group should be identical to that of synthetic drugs. In addition to the need for descriptive monograph on plant material, there is also occasionally a need for reference substances. WHO is assisting in identifying national laboratories which could supply samples of natural substances to be used for reference purposes. WHO has put forth the guidelines for assessment of herbal medicines.

The guidelines address the following points:

1. Pharmaceutical assessment

- Crude plant material

- Plant preparation

- Finished products

- Stability

2. Safety assessment

- Toxicological studies

- Documentation of safety based on experience

3. Assessment of efficacy and intended use

- Pharmacological studies

- Evidence required to support indications

4. Combination products

5. Product information for the consumer.

6. Promotion

The systematic investigation of drugs used in indigenous medicines on modern scientific line has brought into prominence, the merits and qualities of certain drugs and it has been shown that, if brought into general use they may prove to be very valuable addition to the present armamentarium of the medical man to relieve the sufferings of humanity [2]

No detailed Phytochemical and Pharmacological have been done on the plant Bryonia laciniosa, but however some phytochemical studies were carried out on fruits of the plant. It has been reported that the extraction of dry ripe fruit of Bryonia laciniosa with petroleum ether gave $10.2 \%$ dark viscous oil.
Bryonia laciniosa

Family: Cucurbitaceae

\section{Vernacular Names}

Bengal Shiva lingani

Gujarat Shiva lingani

Hindi Gargumaru, Ishwara lingi, Shivalingi

Malayalam Neohmaka

Marathi Shivalingi, Vaduballi

Sanskritpastambhini, Bakapuspha, Shiva Mallika

Telugu Lingadanda

\section{Distribution}

Throughout India from Himalayas to Ceylon, Mauritius, tropical Africa, Malaya, Phillippines, Australia. The plant is an undershrub climber having tendrils. The plant has a bad smell. The plant as a whole is collected after fruiting. It is bitter aperient and tonic. The leaves are applied topically for inflammation.

\section{Morphology}

Stem: Much branched, slender, grooved, glabrous

Tendrils: Slender, striate, glabrous

Leaves: Membraneous, $10-15 \mathrm{~cm}$ long and about as broad, green and scabrid above, paler and smooth or nearly so beneath.

Deeply cordate at base. 5 lobed, the lobes oblong, lanceolate, midrib sometimes subserrate. Petioles $2.5-7.5 \mathrm{~cm}$ long, striate, slender.

Flowers: Male-Small fascicles of 3-6, penduncle 5-20 mm long, filiform, glabrous

Calyx - glabrous, $205 \mathrm{~mm}$ long, teeth subulate Corolla - 3-4 mm long, segments ovate, oblong, acute, pubescent

Female-Solitary or few, or many peduncles shorter than male.

Fruits: Subsessile, $1.3-205 \mathrm{~cm}$ in diameter, globose, smooth, bluish green, streaked with broad vertical lines.

Seeds: 5-6 mm long, yellowish brown [3].

\section{Research Envisaged}

The family Cucurbitaceaehas several important medicinal plants with wide ranging pharmacological and biological activities and interesting chemistry interesting chemistry.In India, this family is reported to have 106 species under 34 genaras. One such is Bryonia with 4 species.

Bryonia diocia,commonly known Brony root is used as cathartic and diuretic and also recommended for Pleurisy, Whooping cough and bronchitis.

Bryonia alba contains a group of triterpenoidal bitter principles having antitumor properties known as cucurbitacins [4].

The selection of the plant Bryonia laciniosa for the present research study was made on the basis of their

- Therapeutic value 
- Degree of research work done, which was not extensive.

Literature survey carried out showed no investigative reports on the phytochemical and pharmacological studies on Bryonia laciniosa. The whole plant of Bryonia Laciniosa is recommended traditionally for inflammation, inducing dieresis and as tonic [3]. Other plants belonging to same genera, like Bryonia dioica, were used traditionally for whooping cough and bronchitis. A systematic photochemical and pharmacological study on this plant was undertaken. What follows is a treatise on the plant Bryonia laciniosa relating it's phytochemical and pharmalogical studies carried out at this institution.

\subsection{Anti Asthmatic Activity}

Asthma is clinical condition in which paroxysmal dyspnoea is accompanied by wheezing due to spasm of bronchial tube or swelling of mucous membrane. Other allergic disorders can also co exist. Recurrence and severity of attack are greatly influence by secondary factors, by mental or physical fatigue, by exposure to fume, by endocrinal secretions. Status asthmaticus, a continuous asthmatic state, may last from hours to days.

Asthma is characterized by an increase in air way resistance which is due to three main factors

- Contraction of smooth muscles in the bronchioles

- Oedema of the bronchiolar mucosa

- Increased bronchiolar secretion

Asthma can be generally classified as either 'Extrinsic' or 'Intrinsic'.

Intrinsic Asthma

In many cases, attack of asthma cannot be attributed to allergic reaction, exact causes are unknown and may be precipitated by infection of the upper or lower respiratory tracts. Such type of asthmatic attack is referred to as intrinsic asthma. Extrinsic Asthma

The etiology of asthma is not completely understood. In some people, asthmatic attack are clearly due to an allergic reaction, this type of asthma is referred to as extrinsic asthma. When such individuals are exposed to some specific allergens, such as dust, fumes, cotton fibres, etc., it leads to the development of specific antibodies (types $\lg \mathrm{E}$ ). Some of these antibodies circulate in blood, but most become attached to the surface of cells, particularly the mast cells. Mast cells are present in nasal cavity, bronchial tissue and mysentery. The IgE antibody can bind specifically to the receptor on the surface of the mast cells and combine with antigen or anti lgE. Re exposure to the original sensitizing antigen results in hyper sensitivity reaction causing disruption of mast cells and release of the contents of their granules into nearby tissues leading to synthesis and release of other mediators which are responsible for bronchial and vascular effect and inflammatory events. The pharmacologically active substance released in the process are Histamine, Serotinin, SRS - A (Slow reacting substance of anaphylaxis), Kinins, Thromboxane-A, Prostaglandins and other potent chemical mediators [5].

For evaluating anti - asthamatic drug, both invivo and invitro models are available. For the in vitro model 'Guinea pig tracheal chain method' is employed. Here the blockade of constriction of trachea (i.e., Dilation) is taken as parameter. In the invivo model protection against histamine Aerosol is employed. Guinea pig is taken as experimental animal.

In the present work, the invivo model employed is mast cells degranulation rate studies by Atopic allergy.

The effect of $70 \%$ alcoholic extract of dried aerial parts of Bryonia laciniosa was based on the degranulation rate of sensitized peritoneal mast cells of albino rats when challenged with antigen. Triple antigen was used as adjuvant and prednisolone was used for comparision as standard [6].

\subsection{Analgesic Activity}

Pain can be defined as the effect produced in consciousness by the arrival in the brain, of nerve impulses generated by noxious stimuli. Pain appears to be caused by the production or liberation of chemical substances by the noxious stimulus. They may themselves stimulate the nocitensive nerve terminals or they may cause other compounds to do so. They may have a local vascular action or they may cause spasm of visceral muscle. [7].

Pain receptor organs are distributed throughout the body. Clinically pain can be considered as:

a. Superficial or cutaneous pain

b. Deep non - visceral pain from muscles, joints, ligaments and bones.

c. Visceral pain

d. Referred pain and

e. Psychogenic or functional pain [8].

It is impossible to know whether the sensation experienced by animals in response to noxious stimuli is qualitatively similar to the pain felt by human beings in similar circumstances.

Different procedures have been used for testing analgesics and are summarized below:

\section{Thermal Method}

A popular method which is applicable to mice uses an electrically heated plate at 55degree C +/- 0.5degree C which is placed in an open cylinder. The mouse is placed in the cylinder and after a latent period it begins to show signs of discomfort, it may rise its hind feet, lick its fore paws or jump out of the cylinder. The last two named signs determine the end points.

The reaction time is noted in seconds at different time intervals after drug administration [9]. 


\section{Mechanical Method}

In this method the pressure is applied on the tail of a rat. Insensitiveness to the applied pressure is the criteria of testing analgesics by pressure methods.

\section{Electrical Method}

Electrodes are implanted or introduced to the skin, scrotum, tail or ear of the experimental animal. The voltage that has to be applied across the electrode (terminals) in order to cause the animals to squeak or struggle is recorded before and after administration of the substances under test.

\section{Chemical Method}

Injection of Phenyl quinine in mice through intra peritoneal route, Benzoquinone, Bradykinin or Acetic acid can also be used. The response to the irritant solution is a characteristic writhing. It is usual to count the number of the total wriths in group of six mice.

\subsection{Anti Convulsant Activity}

Drugs that act upon the CNS are invaluable therapeutically because they can produce specific physiological and psychological effect. Drugs acting on CNS may selectively relieve pain or fever, suppress disorders of movement or prevent seizures. They may induce sleep or arousal, reduce the desire to eat or allay tendency to vomit.

Drugs acting on the CNS may be broadly grouped as

1.CNS stimulants

2.CNS depressants

The CNS depressants are most useful class of therapeutic agents.

They include

1.General anesthetics

2. Hypnotics and sedatives

3.Muscle relaxants

4.Analgesics

5. Tranquilizing agents

6.Anti convulsants

Epilepsy is a collective term used for a group of chronic seizure disorders having in common, sudden and transient episodes (seizures) of loss or disturbance of consciousness, usually but not always with a characteristic body movements (convulsions) and sometimes with autonomic hyperactivity.

Epilepsy can be classified into two major group 1.Tonic clonic seizures / Grandmal / Major epilepsy

This is characterized by sudden loss of consciousness, followed by generalized tonic, followed by clonic convulsive movements. This is followed by a period of headache, drowsiness, confusion and sleep. The attack may be accompanied by tongue biting, frothing at the mouth and in continence.

2.Petit-mal / Absence seizure
It consists of sudden cessation of ongoing conscious activity without convulsive movement and without loss of postural control. The patient appears to go blank for one second to one minute, and may be associated with bilateral clonic motor activity such as eyelid blinking.

John Hughlings Jackson postulated about a century ago that epileptic seizures were caused by "occasional, sudden, excessive, rapid local discharge of grey matter". Modern electrophysiology has amply confirmed this. The characteristic patho physiologic event in a seizure is believed to be paraxysomal depolarization shift of neuronal membrane potential and associated burst discharge. Excitatory neurotransmitters, such as aspartate and glutamate are thought to be involved in the initiation and spread of seizure discharges and the inhibitory transmitter gamma amino butyric acid (GABA) is believed to be responsible for termination of seizure activity. The underlying neuro chemical defect in epilepsy may be a functional impairment in the inhibitory GABA mechanism [8].

For including convulsion commonly used techniques are:

1.Electrical stimulation of brain by maximal electro shock induced method (MES) in rats.

2.Chemical stimulation: Chemical commonly used is pentylene tetrazol.

The analgesic activity of $70 \%$ alcoholic extract of dried aerial part of Bryonia Laciniosa was screened by maximal electro shock induced convulsion in rats.

\section{Materials and Methods 2.1 Collection}

The entire plant with fruits was collected from Bangalore university campus. The plant was washed to remove adhering materials and dried under shades. It was then powdered and sieved through a fine mesh and the fine powder was used for phytochemical and pharmacological investigations.

\subsection{Acute Toxicity Studies of Bryonia laciniosa}

The acute toxicity of the extract was determined by the method of Reed and Meunch [10] on mice. 1.36 Swiss albino mice of either sex weighing between 25-30 gms were divided into 6 groups, each containing six animals.

2.The mice were fasted for 18 hours, with water and libitum.

3.The animals were administered with the suspension of $70 \%$ alcoholic extract in $1 \%$ Tween 80 solutions by oral route.

4.Group 1,2,3,4 and 5 were administered orally with a dose of 250, 500, 1000, 2000 and 3000 $\mathrm{gms} / \mathrm{kg}$ body weight respectively.

5.Group 6 was given 1\% Tween 80 in distilled water and kept as control. 
6 . The number of animals dead in each group, after 72 hours of administration of the drug was recorded and results were tabulated [10].

\subsection{Mesenteric Mast Cell Count by Atopic Allergy Method \\ Principle}

The mechanism behind this model (Atopic allergy) to degranulate mast cell is as follows -

In this classical immunological model, asthma is mediated by reaginie antibodies (Horse serum) bound to mast cells present in the system (Airway mucosa, mysentry etc). On exposure to antigen (Triple antigen), antigen - antibody reaction takes place on the surface of mast cells, subsequent exposure to the allergen (Horse serum) results in hyper sensitivity reaction, leading to degranulation (disruption) of mast cells and release of pharmacologically active agents like Histamine, prostaglandins and other potent chemical mediators are responsible for precipitation of asthma [11].

Material

1.Horse serum (obtained from Veterinary hospital, Bangalore, Turf Club, Bangalore)

2.Triple antigen - containing 20,000 million B. pertusis organism

3.Prednisolone - in a dose of $10 \mathrm{mg} / \mathrm{kg}$ body weight

$4.70 \%$ alcoholic extract of Bryonia laciniosa $300 \mathrm{mg} / \mathrm{kg}$ body weight.

\section{Procedure}

The anti asthmatic activity of $70 \%$ alcoholic extract of Bryonia laciniosa was done by mesenteric mast cell count by Atopic allergy method in rat.

1.Albino rats of either sex weighing between 150200 gms were selected, divided into three groups, each containing six rats.

2. The rats were sensitized by injecting $0.5 \mathrm{ml}$ of horse serum and $0.5 \mathrm{ml}$ of triple antigen subcutaneously.

3.Group I was kept as control without any drug treatment i.e., only distilled water was given during treatment days.

4.Group II was kept as standard and was administered with predisolone $(10 \mathrm{mg} / \mathrm{kg}$ body weight orally). Group III was treated with $70 \%$ alcoholic extract of Bryonia laciniosa in a dose of $300 \mathrm{mg} / \mathrm{kg}$ body weight orally.

5.On the 5th day after sensitization of rats, they were treated with standard and test drug respectively till 12 th day.

6.On the 13th day sensitization, all the animals were sacrificed and the intestinal mesentry was taken for further studies on the mast cells.

7.The mesentries of the sacrificed animals along with pieces of intestine were kept in ringer solution.

8.The mesentry pieces were challenged with horse serum (5\%) for 10 minutes.
9.Later pieces of mesentry were stained superficially with toludine blue. The tissue was first immersed in $0.1 \%$ toludine blue (in $4 \%$ aqueous saline) for 10 minutes [12].

10 .The tissue was then treated with xylene for 510 minutes.

11. Finally it was rinsed with acetone thrice and place on a microscopic slide and stretched with the help of a needle. The intestinal pieces were cut and removed.

12. The tissue was examined under $200 \mathrm{X}$ magnification.

13. The number of intact and disrupted mast cells, in ten randomly selected fields for each tissue was counted. Three slides per each animal were studied.

\subsection{Eddy's hot plate method for estimating analgesic activity Principle}

In this method heat is used as source of pain. Animals are individually placed on a hot plate maintained at constant temperature (55 degree C) and the reaction of the animal such as paw licking or jump response is taken as end point. The method was first described by Eddy and Leimbach.

Materials

Eddy's hot plate analgesiometer maintained at 55 degreeC +/- 0.5degreeC

1. Albino mice of either sex weighing between 20 30 gms

2.Standard drug Ibuprofen in a dose of $100 \mathrm{mg} / \mathrm{kg}$ body weight

3. Bryonia laciniosa ( $70 \%$ alcoholic extract) in a dose of $500 \mathrm{mg} / \mathrm{kg}$ body weight.

The analgesic activity of the $70 \%$ alcoholic extract of dried aerial parts of the plant Bryonia Laciniosa was carried out in mice using Eddy's hot plate analgesio meter [10].

Procedure

1. Albino mice of either sex weighing between 20 30 gms were taken and divided into three groups of six animals each and marked.

2. The animals were fasted for 18 hours prior to the experiment with water ad libitum

3.Group I was kept as control and was administered with distilled water orally. Group II was administered with the standard drug Ibuprofen at a dose of $100 \mathrm{mg} / \mathrm{kg}$ body weight and group III was administered with the test drug at a dose of $500 \mathrm{mg} / \mathrm{kg}$ body weight.

4.After administration of test and standard drug, the test for analgesia was carried out by placing the mice on electrically heated plate at 55 degreeC +/- 0.5 degree $\mathrm{C}$ and noting the signs of discomfort, i.e., it may lick its fore paws or jump out of the plate. The time was noted in seconds. Test was carried out similarly for animals of control group.

5. The observations were made at 30' and 60'. 6 . The results are tabulated. 


\subsection{Electroshock method for estimating anti convulsion activity \\ Principle \\ For inducing convulsion by electro shock, a rectangular pulse current of high voltage (150 $\mathrm{mA}$ ) is employed. The electro shock was given to each rat for 0.2 seconds with the help of convulsion meter through pinna electrodes. Drugs likely to be effective in Grandmal epilepsy usually confer protection against electrically induced convulsion in animals. \\ The MES convulsions are divided into five phases \\ -Tonic flexion \\ -Tonic extension \\ - Clonic convulsion \\ -Stupor \\ -Recovery or death}

A substance is known to posses anticonvulsant property, if it reduces or abolishes the extensor or recovery phase of MES convulsion.

\section{Materials}

1.Electro convulsion meter

2.Standard drug - Carbamazepine in 1\% Tween 80 solution in a dose of $40 \mathrm{mg} / \mathrm{kg}$ bodyweight [13]. $3.70 \%$ alcoholic extract of Bryonia laciniosa in $1 \%$ Tween 80 solution in a dose of $500 \mathrm{mg} / \mathrm{kg}$ body weight.

\section{Procedure}

1.Albino rats of either sex weighing between 150 200 gms were weighed, marked and divided into three groups containing 6 rats each.

2. The animals were fasted for 18 hours prior to the experiment with water ad libitum

3.Group I received carbamazepine $(40 \mathrm{mg} / \mathrm{kg}$ body weight) and Group II received $0.2 \mathrm{ml}$ of $1 \%$ Tween 80 solution and served as standard and control respectively. Similarly Group III received $500 \mathrm{mg} / \mathrm{kg}$ body weight of $70 \%$ alcoholic extract of Bryonia Laciniosa.

4. The electro shock was given to each rat for 0.2 seconds with the help of convulsion meter through pinna electrode and the effects were observed.

5.The results are tabulated.

\section{Results and Discussion}

\subsection{Acute Toxicity Studies of Bryonia} Laciniosa

No mortality was observed up to a dose of $3 \mathrm{gm} / \mathrm{kg}$ body weight. So LD50 of the extract was found to be more than $3 \mathrm{gm} / \mathrm{kg}$ by oral route (Table-1). Hence the drug was found to be nontoxic at the above dose level tested.

\subsection{Anti Asthmatic Activity}

The anti asthmatic activity of $70 \%$ alcoholic extract of Bryonia laciniosa was done by mesenteric mast cell count by Atopic allergy method in rats. The number of intact and disrupted mast cells, in ten randomly selected fields for each tissue was counted. Three slides per each animal were studied. The results of the test and standard in mesenteric studies are given in Table-2.

Increase in \% granulation was recorded in Byonia laciniosa treated samples compared to control. $56.27 \%$ was recorded in Bryonia laciniosa treatment and $81.26 \%$ granulation was recorded in predinisolone (figure-1). Based on graphical picture Percentage protection of Bryonia laciniosa treated samples over control increased significantly and the value was 43.88 (figure-2). Based on statistical analysis't' value for Bryonia laciniosa treatment was 4.857 (Table-3).

\subsection{Analgesic Activity}

The analgesic activity of the $70 \%$ alcoholic extract of dried aerial parts of the plant Bryonia laciniosa was carried out in mice using Eddy's hot plate analgesio meter. After administration of test and standard drug, the test for analgesia was carried out by placing the mice on electrically heated plate at 55degreeC $+/-0.5$ degree $C$ and noting the signs of discomfort, i.e., it may lick its fore paws or jump out of the plate. The time was noted in seconds. Test was carried out similarly for animals of control group. The observations were made at 30 ' and 60'. The results were tabulated in Table-4. It was found that Bryonia laciniosa showed fairly good analgesic activity at 30 and 60 minutes when compared with standard drug.

Bryonia laciniosa treated group showed an increase in response time to pain stimuli when compared to the control group (Table-4). The increase in response time was from 5.83 to 8.50 seconds at 30 minutes and from 5.67 to 10.50 seconds after 1 hour of treatment. Response time to pain stimuli shown by Morphine sulphate was 15.33 and 18.17 seconds respectively after 30 and 60 minutes of treatment. Statistical test revealed that analgestic activity was significantly increased in Bryonia laciniosa treated group (Table-5).

\subsection{Anti Convulsant Activity}

For inducing convulsion by electro shock, a rectangular pulse current of high voltage (150 $\mathrm{mA}$ ) is employed. The electro shock was given to each rat for 0.2 seconds with the help of convulsion meter through pinna electrodes. Drugs likely to be effective in Grandmal epilepsy usually confer protection against electrically induced convulsion in animals. Group I received carbamazepine(40mg/kg body weight) and Group II received $0.2 \mathrm{ml}$ of $1 \%$ Tween 80 solution and served as standard and control respectively. Similarly Group III received $500 \mathrm{mg} / \mathrm{kg}$ body weight of $70 \%$ alcoholic extract of Bryonia laciniosa. The electro shock was given to each rat for 0.2 seconds with the help of convulsion 
meter through pinna electrode and the effects were observed. The results are tabulated (Table$6)$.

In Bryonia laciniosa treated group \% reduction of extensor phase was 39.27. In Carbemazepine treated group \% reduction of extensor phase was 95.58. The statistical analysis revealed that there was significant increase in anticonvulsant activity in the case of Bryonia laciniosa treated group (Table-7).

\section{Summary}

The whole plant of Bryonia laciniosa is recommended traditionally for inflammation, inducing dieresis and as tonic. Other plants belonging to same genera, like Bryonia dioica, were used traditionally for whooping cough and bronchitis. The entire plant with fruits was collected from Bangalore university campus. The plant was washed to remove adhering materials and dried under shades. It was then powdered and sieved through a fine mesh and the fine powder was used for phytochemical and pharmacological investigations.

The anti asthmatic activity of $70 \%$ alcoholic extract of Bryonia laciniosa was done by mesenteric mast cell count by Atopic allergy method in rats. The number of intact and disrupted mast cells, in ten randomly selected fields for each tissue was counted. Increase in \% granulation was recorded in Bryonia Laciniosa treated samples compared to control. 56.27\% was recorded in Bryonia Laciniosa treatment and $81.26 \%$ granulation was recorded in predinisolone. Percentage protection of Bryonia laciniosa treated samples over control was 43.88. Based on statistical analysis't' value for Bryonia laciniosa treatment was 4.857 .

Analgesic activity of $70 \%$ alcoholic extract of Bryonia laciniosa was screened by Eddy's Hot plate method. Morphine sulphate was used as standard for comparing the analgesic activity of Bryonia laciniosa. It was found that Bryonia laciniosa showed fairly good analgesic activity at 30 and 60 minutes when compared with standard drug. Bryonia laciniosa treated group showed an increase in response time to pain stimuli when compared to the control group. The increase in response time was from 5.83 to 8.50 seconds at 30 minutes and from 5.67 to 10.50 seconds after 1 hour of treatment. Response time to pain stimuli shown by Morphine sulphate was 15.33 and 18.17 seconds respectively after 30 and 60 minutes of treatment.

For inducing convulsion by electro shock, a rectangular pulse current of high voltage (150 $\mathrm{mA}$ ) is employed. The electro shock was given to each rat for 0.2 seconds with the help of convulsion meter through pinna electrodes.
Drugs likely to be effective in Grandmal epilepsy usually confer protection against electrically induced convulsion in animals. In Bryonia laciniosa treated group \% reduction of extensor phase was 39.27. In Carbemazepine treated group \% reduction of extensor phase was 95.58. The statistical analysis revealed that there was significant increase in anticonvulsant activity in the case of Bryonia laciniosa treated group.

\section{Conclusion}

Based on the results we concluded that $70 \%$ alcoholic extract of Bryonia laciniosa increased the antiasmatic activity, analgestic activity and also anticonvulsant activity in rat. The drug was found to be nontoxic. By doing further research in Bryonia laciniosa even we can develop phytotherapeutics for Asthma, Epilepsy. Also we can use Bryonia laciniosa as pain reliever.

\section{References}

[1] Trease G.E., Evans W. (2003) Textbook of Pharmacognosy 13th ed Elsevier India Pvt.Ltd Noida, 345-456.

[2] Chopra R.N., Chopra I.C., Handa K.L. and Kapur L.D. (1976) Chopra's Indigenous Drugs of India. 2nd ed. U. N. Dhur and Sons Private Ltd., Calcutta, 61-3.

[3] Kiritikar K.R. and Basu B.D. (1987) Indian Medicinal Plants, Vol. II, 2nd ed., published by Lalit Mohan Basu, Allahabad, India, 1023-28.

[4] Wallis T. E. (2006) Textbook of Pharmacognosy, 5th Edition.,680-698.

[5] Lichtenstein L.M. (1977), Mechanisms of allergic inflammation. Progress in Immunology-III: Edited by TE Mandel et al, North Holland Publishing, Amsterdam, pp 430-438.

[6] Gupta D.K., Singhvi A. K., Sanwal D. N. and Rao G. N. (1973) Hyperfine-Field Measurements on $\mathrm{Sc}$ in $\mathrm{Fe}$ and $\mathrm{Re}$ in $\mathrm{Ni}$ Phys. Rev. B 7, 2942-2947.

[7] Lewis G. P. and Whittle I'. J. I'. (1977) Br. J. Pharmacol, 61,229-235.

[8] Satoskar R.S., Bhandarkar S.D., Nayak V.K., Desai N.K., Kshirsagar N.A. (1991) J. Postgrad Med.,37(1):5-8.

[9] Eddy N. B. and Leimbach D. (1953) J. Pharmacol. Exp. Ther. 107, 385-393.

[10] Turner R.A. (1965) Screening methods in Pharmacology, Academic Press, NewYork, Vol I, pp 69-86.

[11] Katzung B.G. (2007) Basic and Clinical Pharmacology. 10th Edn., McGraw Hill Companies Inc., New Delhi.

[12] Norton S. (1954) Br. I. Phamacol., 9, 494497.

[13] Kadlimatti S.H., Joseph T. (1987) Indian J Physiol Pharmacol.,31(1):35-41. 
Table-1 Acute Toxicity Studies of Bryonia Laciniosa

\begin{tabular}{|c|c|c|c|c|c|c|c|}
\hline \multirow[t]{2}{*}{ GROUP } & \multirow{2}{*}{$\begin{array}{l}\text { NO. OF } \\
\text { ANIMALS IN } \\
\text { THE GROUP }\end{array}$} & \multirow{2}{*}{$\begin{array}{l}\text { AVE. } \\
\text { WEIGHT OF } \\
\text { ANIMALS }\end{array}$} & \multirow[t]{2}{*}{$\begin{array}{l}\text { DOSE } \\
\mathrm{mg} / \mathrm{kg}\end{array}$} & \multicolumn{3}{|c|}{ DEATH AFTER } & \multirow{2}{*}{$\begin{array}{l}\text { NO. OF } \\
\text { SURVIVED } \\
\text { ANIMALS }\end{array}$} \\
\hline & & & & $\begin{array}{l}24 \\
\text { hour }\end{array}$ & $\begin{array}{l}48 \\
\text { hour }\end{array}$ & $\begin{array}{l}72 \\
\text { hour }\end{array}$ & \\
\hline $\mathrm{I}$ & 6 & 29.33 & 250 & -- & -- & -- & 6 \\
\hline II & 6 & 28.67 & 500 & -- & -- & -- & 6 \\
\hline III & 6 & 27.00 & 1000 & -- & -- & -- & 6 \\
\hline IV & 6 & 27.33 & 2000 & -- & -- & -- & 6 \\
\hline $\mathrm{V}$ & 6 & 30.83 & 3000 & -- & -- & -- & 6 \\
\hline
\end{tabular}

Table-2 Data Showing Degranulation and Granulation of Mast Cells

\begin{tabular}{|l|l|l|l|}
\hline TREATMENT & CONTROL & PREDNISOLONE & $\begin{array}{l}\text { BRYONIA } \\
\text { LACINIOSA }\end{array}$ \\
\hline DOSE & $\mathbf{0 . 2} \mathbf{~ m l ~ S a l i n e ~}$ & $\mathbf{1 0 ~} \mathbf{~ g} / \mathbf{k g}$ & $\mathbf{3 0 0} \mathbf{~} \mathbf{g} / \mathbf{k g}$ \\
\hline $\begin{array}{l}\text { WT. OF ANIMALS IN } \\
\text { gm +/- SEM }\end{array}$ & $\begin{array}{l}170.83+/ \\
5.85\end{array}$ & $165.17+/-3.25$ & 165.005 .45 \\
\hline $\begin{array}{l}\text { DEGRANULATED } \\
\text { CELLS(X) +/- SEM }\end{array}$ & $16.26+/-0.5$ & $4.29+/-0.38$ & $9.9+/-0.35$ \\
\hline $\begin{array}{l}\text { GRANULATED CELLS } \\
\text { (Y) +/- SEM }\end{array}$ & $4.6+/-0.39$ & $18.74+/-1.33$ & $12.83+/-0.23$ \\
\hline TOTAL (X+Y)+/- SEM & $20.87+/-0.85$ & $23.02+/-1.47$ & $22.83+/-0.35$ \\
\hline $\begin{array}{l}\text { \%DEGRANULATIN +/- } \\
\text { SEM }\end{array}$ & $77.92+/-1.71$ & $18.74+/-1.56$ & $43.73+/-1.12$ \\
\hline $\begin{array}{l}\text { \%GRANULATIN +/- } \\
\text { SEM }\end{array}$ & $22.08+/-1.70$ & $81.26+/-1.56$ & $56.27+/-1.12$ \\
\hline \%PROTECTION & -- & 75.95 & 43.88 \\
\hline
\end{tabular}

Table-3 Statistical Data For Anti Asthmatic Activity

\begin{tabular}{|l|l|l|}
\hline GROUP & $\begin{array}{l}\text { PREDNISOLONE treated } \\
\text { group }\end{array}$ & $\begin{array}{l}\text { BRYONIA LACINIOSA } \\
\text { Treated group }\end{array}$ \\
\hline CALCULATED 't' VALUE & 12.9032 & 4.6999 \\
\hline TABLE 't' VALUE & 4.587 & 4.587 \\
\hline REMARKS & Significant & Significant \\
\hline
\end{tabular}

Table-4 The Analgesic Activity of 70\% Alcoholic Extract of Bryonia Laciniosa by Eddy's Hot Plate Method

\begin{tabular}{|c|c|c|c|c|}
\hline \multirow{2}{*}{ TREATMENT } & \multirow{2}{*}{$\begin{array}{l}\text { WT. OF } \\
\text { ANIMALS IN } \\
\text { gms +/- SEM }\end{array}$} & \multirow{2}{*}{$\begin{array}{ll}\text { DOSE } & \text { IN } \\
\mathrm{mg} / \mathrm{kg} & \\
\text { BODY } & \\
\text { WEIGHT } & \end{array}$} & \multicolumn{2}{|c|}{$\begin{array}{l}\text { RESPONSE TIME IN SEC +/- } \\
\text { SEM }\end{array}$} \\
\hline & & & 30 minutes & 60minutes \\
\hline Control & $20.83+/-0.83$ & -- & $05.83+/-0.31$ & $\begin{array}{l}05.67 \\
0.42\end{array}$ \\
\hline $\begin{array}{l}\text { Morphine } \\
\text { Sulphate }\end{array}$ & $26.33+/-0.95$ & 100 & $15.33+/-0.49$ & $\begin{array}{ll}18.17 & +/- \\
0.75\end{array}$ \\
\hline $\begin{array}{l}\text { Bryonia } \\
\text { Laciniosa }\end{array}$ & $27.00+/-1.13$ & 500 & $08.50+/-0.43$ & $\begin{array}{l}10.50 \quad+/- \\
0.50\end{array}$ \\
\hline
\end{tabular}


Table-5 Statistical Data for Analgesic Activity

\begin{tabular}{|l|l|l|l|l|l|l|}
\hline & \multicolumn{3}{|c|}{30 MINUTES } & \multicolumn{3}{c|}{60 MINUTES } \\
\hline GROUP & $\begin{array}{l}\text { Calculated } \\
\text { 't' value }\end{array}$ & $\begin{array}{l}\text { Table } \\
\text { 't' } \\
\text { value }\end{array}$ & Remark & $\begin{array}{l}\text { Calculated } \\
\text { 't' value }\end{array}$ & $\begin{array}{l}\text { Table } \\
\text { 't' value }\end{array}$ & Remark \\
\hline $\begin{array}{l}\text { Morphine } \\
\text { Sulphate }\end{array}$ & 16.3176 & 4.587 & Significant & 14.5492 & 4.587 & Significant \\
\hline $\begin{array}{l}\text { Bryonia } \\
\text { Laciniosa }\end{array}$ & 5.068 & 4.587 & Significant & 7.3882 & 4.587 & Significant \\
\hline
\end{tabular}

Table-6 The Anti Convulsant Activity of 70\% Alcoholic Extract of Bryonia Laciniosa By MES Method.

\begin{tabular}{|l|l|l|l|}
\hline TREATMENT & CONTROL & CARBAMAZEPINE & $\begin{array}{l}\text { BRYONIA } \\
\text { LACINIOSA }\end{array}$ \\
\hline WT. IN gm +/- SEM & $166.33+/-6.4$ & $144.67+/-14.63$ & $171.17+/-6.23$ \\
\hline $\begin{array}{l}\text { DOSE IN mg/kg BODY } \\
\text { WT. }\end{array}$ & $0.2 \mathrm{ml}$ & 40 & 500 \\
\hline FLEXION & $3.00+/-0.365$ & $13.33+/-0.333$ & $2.33+/-0.211$ \\
\hline EXTENSOR & $15.10+/-0.477$ & $0.667+/-3.674$ & $9.17+/-0.645$ \\
\hline CLONIC & $1.83+/-0.167$ & $0.33+/-0.211$ & $1.17+/-0.307$ \\
\hline STUPOR & $127.0+/-2.082$ & $47.37+/-8.361$ & $90.0+/-3.795$ \\
\hline RECOVERY OR DEATH & RECOVERED & RECOVERED & RECOVERED \\
\hline $\begin{array}{l}\text { \%REDUCTION OF } \\
\text { EXTENSOR PHASE }\end{array}$ & -- & 95.58 & 39.27 \\
\hline $\begin{array}{l}\text { Animal - Rats (150-200 gms) } \\
\text { Route - Oral }\end{array}$ & & \\
\hline
\end{tabular}

Table-7 Statistical Data For Anti Convulsant Activity

\begin{tabular}{|l|l|l|}
\hline GROUP & $\begin{array}{l}\text { CARBAMAZEPINE } \\
\text { TREATED GROUP }\end{array}$ & $\begin{array}{l}\text { BRYONIA LACINIOSA } \\
\text { TREATED GROUP }\end{array}$ \\
\hline Calculated 't' value & 14.9867 & 5.7833 \\
\hline Table ' $t$ ' value & 4.587 & 4.587 \\
\hline Remarks & Significant & Significant \\
\hline
\end{tabular}

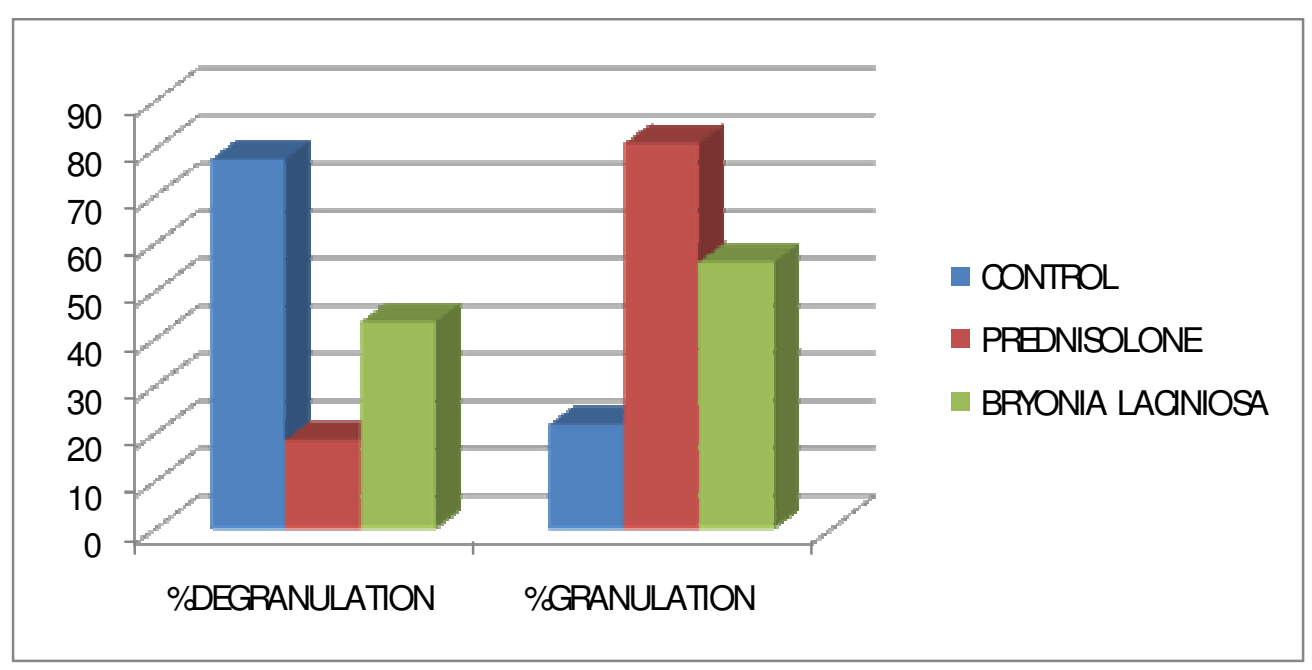

Fig. 1- Percentage Degranulation and Granulation of Mast Cells 


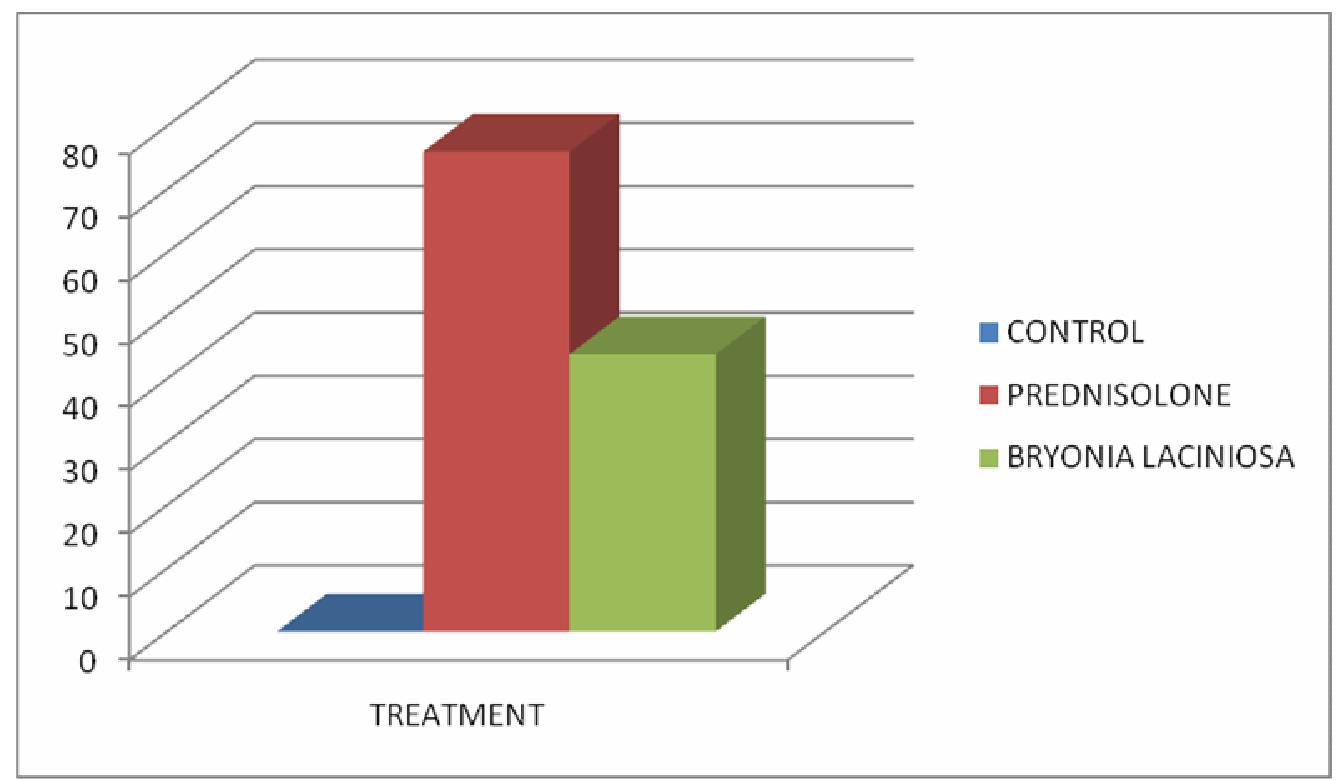

Fig. 2- Percentage Protection of Prednisolone and Byonia Laciniosa against Mast Cell Degranulation 